$20 \mid 2019$

Sedition, Sexuality, Gender, and Gender Identity in South Asia

Dissenting Differently: Solidarities and Tensions between Student Organizing and Trans-Kothi-Hijra Activism in Eastern India

\title{
Aniruddha Dutta
}

\section{CpenEdition}

\section{Journals}

Electronic version

URL: http://journals.openedition.org/samaj/5210

DOI: 10.4000/samaj.5210

ISSN: $1960-6060$

Publisher

Association pour la recherche sur l'Asie du Sud (ARAS)

Electronic reference

Aniruddha Dutta, "Dissenting Differently: Solidarities and Tensions between Student Organizing and Trans-Kothi-Hijra Activism in Eastern India", South Asia Multidisciplinary Academic Journal [Online], 20 I 2019, Online since 08 April 2019, connection on 10 March 2021. URL: http://journals.openedition.org/ samaj/5210 ; DOI: https://doi.org/10.4000/samaj.5210

This text was automatically generated on 10 March 2021

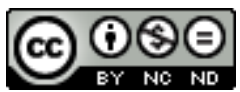

This work is licensed under a Creative Commons Attribution-NonCommercial-NoDerivatives 4.0 International License. 


\title{
Dissenting Differently: Solidarities and Tensions between Student Organizing and Trans-Kothi-Hijra Activism in Eastern India
}

\author{
Aniruddha Dutta
}

\section{Introduction}

On the 21st of December at 9:30 pm, five of us trans persons ... were standing and waiting for two other friends ... when seven-eight men ... began verbally abusing us ... we protested ... (they) started raining blows on us ... we register our strong protest against this incident. (Babui 2015) ${ }^{1}$

1 The above quote, illustrating a particular incident of transphobic violence, is excerpted from an "open letter" in Bengali authored by activists associated with Samabhabona, a transgender community organization based in Kolkata, the capital of the state of West Bengal in eastern India. The letter was circulated as a public post on Facebook on January 1, 2015. Remarkably, apart from the trans collective that authored it, the letter was mainly disseminated by cisgender-heterosexual student activists based in universities in Kolkata, rather than by LGBT groups and non-governmental organizations (NGOs) working in the area. The subsequent street protest was also largely attended by students, in addition to the affected trans persons. This gathering spurred protests against similar incidents elsewhere in the state, organized through coalitions between student activists and transgender/queer groups, particularly collectives of largely working class and Dalit (oppressed caste) communities such as kothis and hijras. These terms signify a regionally varied spectrum of feminineexpressing persons usually assigned male at birth-including transgender women, feminine males and people with fluid or overlapping subject positions-who may also refer to themselves as transgender or gay in Anglophone contexts (Dutta and Roy 2014). ${ }^{2}$ 
2 How and why did such alliances emerge between trans-kothi-hijra groups and non-LGBT student collectives with, in some cases, trans/queer collectives even preferring to collaborate with student activists rather than other LGBT organizations? In this article, I explore some of the solidarities and tensions that have developed in this emergent political terrain, drawing on participant observation, collaborative activism and dialogues with kothi-hijra and student activists, conducted between 2012 and 2017. The first three sections of the article chart how alliances emerged between the trans feminine kothi-hijra spectrum and leftist-feminist student collectives based in and around Kolkata, creating new political configurations and possibilities. I argue that these alliances challenge the hegemony of single-axis identity politics based on gender or sexuality alone, and emphasize the role of intersections based on class, caste and language in the process of movement building. Under certain circumstances, transkothi-hijra collectives may prefer to work with student groups associated with proworking-class politics, rather than LGBT organizations dominated by upper class/caste activists. Referencing Raka Ray's (1999) theorization of the hegemonic "political field" of Kolkata (p. 49), I argue that such alliances interrupt established fields of both leftist and LGBT politics in India. On one hand, they destabilize a primary emphasis on class on the left, on the other, they underscore the importance of class/caste politics within LGBT mobilizations.

3 However, subsequent sections of the article go on to show how these alliances evidence an unpredictable oscillation between the subversion of hegemonic political fields and the reinscription of hierarchies within activist spaces, which challenges a linear teleology of political progress. Rather, as I attempt to demonstrate, these evolving coalitions reveal both "paradoxes and possibilities" (Roy 2012:3)-such as emerging intersectional critiques that bridge feminist, Marxist and trans/queer politics, versus persistent hierarchies of class, caste and gender within coalitional spaces that circumscribe the potentials of student-trans solidarities. Indeed, radical political agendas may co-exist with disciplinary and governmental technologies of power that seek to regulate "proper" revolutionary conduct. This analysis resonates with recent examinations of governance within feminist activism (Roy 2017:3), and examines how strategies of governance function in spaces of leftist-feminist student activism. However, while much of the analysis of feminist governance has focused on funded, institutionalized forms of activism (Soderlund 2005; Karim 2011; Roy 2017), I explore forms of governance within amorphous, informally structured and non-funded alliances. Such collaborative activist spaces evidence non-linear and non-teleological tendencies, such that hierarchizing maneuvers and governmental technologies may be ruptured even as they are consolidated, rather than crystallizing into an institutionalized pattern.

4 I analyze this unstable terrain as symptomatic of larger tensions between, on the one hand, hierarchical structures and ideological authoritarianism that have long characterized the organized left in India, and on the other, challenges to hegemonic leftist structures and discourses. Such challenges were enabled by the emergence, in the 2010s, of an "independent" left in West Bengal, unaffiliated with any political party. This shift is marked by ideological clashes between the traditional left and independent student collectives, and within the independent left itself, as student activists interrogate orthodox left positions and seek to define their stances around issues like sexuality, transgender politics and sex workers' rights, which were typically dismissed 
or neglected by the left. While this process is marked by ideological factions and debates, repertoires of political concepts and rhetorical strategies also unpredictably travel between seemingly opposed sides, undoing rigid dichotomies of political praxis.

of course, student politics and the LGBT movement in India are each richly diverse terrains in their own right, and this cannot claim to be a comprehensive analysis of either, or even of all intersections between the two. Rather, this article focuses on specific conjunctures that developed between leftist student collectives and trans/ queer groups in the 2010s. It is written as a series of reflections from the vantage point of personal experiences-including my own-meant to spark reflection and dialogue across academic and activist spaces.

\section{Charting emerging solidarities}

6 In several ways, the year 2012 marked a turning point for the LGBT movement and associated communities in Kolkata and West Bengal. It was a year of disillusionment for many, especially for trans-kothi-hijra people who worked in HIV-prevention projects funded by the Indian government's AIDS control departments, which supported several LGBT NGOs in the state. In 2012, the West Bengal state AIDS control department stopped funding MANAS Bangla, a network of community-based HIV prevention projects, due to alleged financial corruption by senior staff, thus depriving hundreds of trans-kothi-hijra workers of their livelihood (Dutta 2012). Several junior staff from kothi and hijra communities complained to me that the upper class-caste leadership of the network did nothing, beyond making a few token protests, to protect their interests. Some of the discharged staff went on to work at other LGBT organizations, but even there, they encountered exploitative labor dynamics, including salary cuts and misappropriation of funds meant for workers. The limits of single-axis identity politics that emphasized gender/sexual rights, but ignored class/caste hierarchies within LGBT spaces, became increasingly evident in the growing sense of disillusionment with the LGBT leadership among many transgender, kothi and hijra people. This was exacerbated by the gentrification of activist spaces such as the annual Kolkata rainbow pride walk, which was increasingly appropriated by middle class LGBT people.

7 This larger context prompted trans-kothi-hijra activists to look beyond LGBT spaces and seek alliances with a variety of leftist, feminist, Dalit and students' movements in West Bengal. Solidarities between trans-queer activists and students, in particular, intensified in the aftermath of the rape and murder of Jyoti Singh Pandey, a young female physiotherapy student who was sexually assaulted and tortured in a moving bus in Delhi in December 2012. She later succumbed to her injuries (Mandhana and Trivedi 2012). Like elsewhere in the country, this incident prompted a spate of protests in West Bengal. A spectrum of leftist and feminist student groups were involved in these actions, which placed gender and sexuality at the forefront of student activism in an unprecedented way. Trans/queer communities such as the kothi-hijra spectrum joined these protests, and used them as a platform to bridge the issue of violence against cisgender women with gender/sexual violence against LGBT and especially trans feminine people.

8 Unlike cities like Delhi that have had active queer campus collectives since the 2000s, the initial intersections between LGBT and student activism in West Bengal typically developed as alliances between largely cisgender heterosexual student communities 
and trans/queer groups located outside campus spaces, with queer student groups emerging later. ${ }^{3} \mathrm{~A}$ few trans/kothi activists deserve special mention for their pioneering role in these early dialogues: Anurag Maitreyee, Bobby Kamalini De, and Raina Roy in Kolkata, and Sumi Das in North Bengal. ${ }^{4}$ Among them, I collaborated particularly with Raina and Sumi in initiating dialogues with student groups. Responding to advocacy by these activists, several student collectives also started including LGBT issues in their agendas. One of the most active groups in this field was Ardhek Akash or "Half the sky," a loosely organized and non-funded feminist collective comprising a floating population of students and alumni from Presidency, Jadavpur and Kolkata Universities, as well as small-town colleges. Ardhek Akash, which began as a magazine on women's rights in 2006 and later expanded into an initiative against gender-based discrimination, comprises people from a variety of socioeconomic positions, including upper-caste men and Dalit women. It is associated with other overlapping student outfits like Jubo Andolon Moncho or the Revolutionary Youth Forum. None of these collectives are associated with any political party and they position themselves as part of a larger non-party left, sometimes referred to as the tritiyo front or third front.

Such collectives are situated within the larger diversified terrain of student politics in West Bengal, which features both structured, organized fronts and more unstructured, fluid groups. Student politics in Bengal has traditionally been tilted toward the left, but also evidences the increasing presence of right-wing groups. There are at least three broad elements within this terrain: firstly, organized student groups affiliated with political parties, for example the ABVP (Akhil Bharatiya Vidyarthi Parishad) affiliated with the right-wing Bharatiya Janata Party (BJP); the Trinamool Chatra Parishad, affiliated with the centrist and populist Trinamool Congress (TMC); the Students' Federation of India (SFI) affiliated with the Communist Party of India (Marxist) or CPI(M); AISA (All India Students' Association), affiliated with the Communist Party of India (Marxist-Leninist) Liberation, and so on. Secondly, there are more "independent" but structured groups with formal membership, like the PDSF (Progressive Democratic Students' Federation) or the USDF (United Students' Democratic Front), which are to the far left, but not explicitly associated with any party. Some independent groups focus on specific campuses, for example the Independents' Consolidation (IC) at Presidency University, or the Forum for Arts Students (FAS) at Jadavpur University. Independent groups tend to be suspicious of party-affiliated organizations-even leftist ones-and have attempted to wrest control of student unions from party-affiliated groups (The Telegraph 2015). Lastly, there are more amorphously structured independent political platforms or collectives that do not contest student elections. They have fluid boundaries and a floating membership, which may spring up or dissipate around particular issues, causes or initiatives. These groups, such as Students for Democracy, Jubo Andolon Moncho and Ardhek Akash, often utilize social media platforms to recruit volunteers, rather than a formalized membership process. Collectives of this type participated in, and drew inspiration from, "independent" nonparty-affiliated student mobilizations in Kolkata in the 2010s, such as a series of protests at Jadavpur University in 2014 against the university administration's handling of a case of sexual molestation and subsequent police brutality against student protestors. This came to be known as the Hok Kolorob movement, based on its slogan "Hok Kolorob" or "let there be noise" (Ghoshal 2014). However, students from party-affiliated outfits or structured independent groups may also float in and out of initiatives organized by these collectives. 
10 It is these independent, loosely structured groups that were most amenable to the early intersections between student and trans/queer activism. Several of these student groups actively organized protests against Section 377 of the Indian Penal Code (1860) a colonial-era law that criminalized non-peno-vaginal sexual intercourse and was occasionally used against LGBT people, before the Indian Supreme Court partially struck it down to exclude consensual sexual activity from its purview in 2018 (Rajagopal 2018). In turn, trans/queer communities also joined in student-led protests during the Hok Kolorob movement.

\section{Beyond gender/sexuality: solidarities around class, caste and language}

11 A major factor underlying the coalitions between student and trans activists is solidarity based on class and language, rather than on gender or sexual identity, although a shared sense of gender-sexual politics remains important. As mentioned above, the elite character of the LGBT leadership became increasingly clear to many trans, kothi and hijra people following the debacle of MANAS Bangla in 2012. Among the aforementioned activists, Raina comes from an urban upper caste, yet lower middle class family, while Sumi hails from a rural Dalit background. Both experienced exploitative working conditions as well as humiliation and abuse by upper class/caste leaders while employed as lower-end staff in HIV projects run by NGOs. This eventually led them to quit these jobs and form collectives with kothi-hijra people of similar socioeconomic backgrounds. In this context, leftist student groups offered a more explicitly class-oriented political platform that promised greater equality. Further, several kothi and hijra community members in Kolkata told me on various occasions that they were more comfortable in Bengali-speaking student spaces than in Anglophone LGBT contexts. For example, Anindita and Ragini, two Dalit trans women who work with Raina at the abovementioned trans collective Samabhabona, expressed their discomfort with attending seminars and panel discussions organized by funded NGOs: “everything is in English ... don't take us to such spaces. We much prefer to go to events organized by Ardhek Akash or by Dalit groups." ${ }^{5}$ Raina herself praised the ways in which Ardhek Akash produced accessible leftist and feminist material in Bengali: "they make a lot of posters in Bengali ... and do it really well."

The posters and slogans used by Ardhek Akash and similar student groups represent an amalgamation of various discursive tendencies ranging from liberal to Marxist feminism, adjusted to the demands of the occasion, and largely expressed in colloquial Bangla. ${ }^{6}$ For example, some posters carry messages against rape culture and violence against women, such as "stop the patriarchal viewpoint of questioning the clothes a rape victim was wearing", or "marriage gives the legal right to rape every night." Others deploy liberal humanist standpoints to critique patriarchal constructions of gender, such as "softness, caring and forgiveness should not be feminine but human virtues." Occasions such as International Women's Day are used to articulate Marxist feminist demands for better working conditions for domestic workers. This convergence of distinct (but not necessarily opposed) political registers has proven amenable to the incorporation of LGBT issues. Since 2013, posters protesting violence against LGBT people also began to appear at Ardhek Akash events, bearing messages 
such as "stop sexual violence and corrective rape against people of marginalized sexualities (prantikjounotar manush)."

\section{Challenging hegemonic fields of left and LGBT politics}

13 Trans people have used this flexible discursive space to critique hierarchies within the LGBT NGO sector and to build alliances that subvert the domination of elite LGBT leaders. In a meeting with Ardhek Akash in December 2014, community members associated with Samabhabona articulated a strong critique of how, in their words, "NGOs are selling communities for funding." This was a reference to the way NGOs used kothis and hijras as target groups to obtain funded HIV-prevention projects, while simultaneously exploiting them and neglecting their needs. Ragini, a Dalit trans and kothi-identified person, narrated how she had approached an NGO after being assaulted, but the organization put the onus of filing a complaint on her, and did not follow up on the case. Those present at the meeting decided to create a collaboration between Ardhek Akash and Samabhabona, which would directly intervene at sites of transphobic violence and harassment through protests and advocacy meetings, especially in non-metropolitan areas neglected by funded LGBT activism. This ongoing collaboration has sought to shift the movement's priorities from a narrow focus on sexual health in the HIV sector and celebratory and performative events like Pride walks, to put the emphasis back on countering violence against poor trans-kothi-hijra people.

These collaborations also mark a critical departure from traditional forms of leftist politics in India. As in the West, the organized left in India has long been critiqued for perpetuating gender and caste hierarchies within and beyond party ranks (Kranz 2015:153; Desai 2016:13). Organizational hierarchies reproduce the ideological deprioritization of gender and caste relative to class. Social actions focusing on gender or caste may be seen as fringe or elite issues in comparison to "mass-based" struggles, and even as fracturing or undermining mass unity (Omvedt 1994:37; Kranz 2015:239). Upper-caste male leaders of leftist political parties have even decried such movements as "imperialist plots" (Omvedt 1994:37).

Such dismissals extend to LGBT issues-most parties within the traditional left in West Bengal and India have been homophobic and transphobic. While the CPI(M) has come around to supporting LGBT rights, other parties such as the SUCI(C) (Socialist Unity Center of India (Communist)) still vociferously oppose LGBT issues as imperialist and bourgeois (Muktangan 2009). In 2009, after a Delhi High Court judgment temporarily removed consensual same-sex behavior from the purview of IPC 377 (Indian Penal Code 1860), Nihar Mukherjee, general secretary of the SUCI(C) said, "this judgment ... will simply open the floodgate of degraded degenerated imperialist culture that ... instigates perversion and sexual promiscuity with the vile objective of destroying the very moral backbone of ... the youth. This nefarious design ... is being assiduously pursued by the ruling capitalist class ... to disturb growth and development of revolutionary movement based on ... higher ethics and culture" (Muktangan 2009). Such evocations of anti-imperialism end up mirroring right-wing condemnations of LGBT practices and identities as foreign incursions. They underscore nationalist and protectionist understandings of Indian "culture," marking political continuities 
between the "left" and the "right," and the discursive transfer of common tropes across apparently opposed ideological frames.

Such tendencies also mark the domination of men from the "Bhadralok" class (upper caste Bengalis) within left spaces. According to Raka Ray (1999), in comparison to other Indian metropolises like Mumbai, Kolkata evidenced a more uniformly hegemonic political field "with concentrated power and a homogeneous culture" ruled by the ostensibly leftist CPI(M) (p.49). However, in the 2000s, this hegemonic field was ruptured when attempts by the ruling CPI(M) to acquire land for corporate interests were opposed by powerful farmers' movements at singur and Nandigram. These protests garnered widespread support and led to the electoral defeat of the CPI(M) and the rise of the Trinamool Congress (TMC) that came into power in 2011 (Bose 2011).

In this context, leftist students dissatisfied with the repressive tendencies of the traditional left joined and bolstered "independent" fronts. During the "Hok Kolorob" protests at Jadavpur University, many student activists, including members of Ardhek Akash, opposed both the TMC and the CPI(M) for their deployment of statist machinery and police violence, and hailed Hok Kolorob as a bannerless, independent, non-party movement. As one activist said, "it is political but ... independent of the clutches of political parties ... independent from ... age-old governmental, power-centric political organizations of different colours but of similar vested interests" (Times News Network 2014). To date, the cover photo of Ardhek Akash's public group on Facebook exhorts readers to "pledge to take initiatives in their own spaces outside conventional party banners," underlining an ethic of independent mobilization that resists institutional consolidation. ${ }^{8}$

In this changing scenario, student mobilizations became more sensitive to issues of gender-sexuality and caste, particularly after the anti-rape protests of December 2012 that helped shift the focus from single-issue class politics. Living in a family of active SUCI(C) workers, Raina had personally experienced the oppressive effects of leftist conservatism and she utilized this conjuncture to enter "independent" leftist spaces. In July 2013, Raina and I were invited to a panel discussion on rape culture at Presidency University, organized by Ardhek Akash. The description of the event announced: "Ardhek Akash opposes any kind of violence based on gender discrimination, not just violence against (cisgender) women." This marked a significant shift within the discursive sphere of anti-rape protests in Kolkata. As Raina said, "subsequently, I started sitting on various student panels ... associated myself with left-liberal politics ... gradually I understood that only students can bring about change through their unity!"

The departure from the erstwhile hegemony of the left crystallized in December 2013, when the Indian Supreme Court overruled the aforementioned Delhi High Court judgment and reinstated IPC 377, although it eventually struck down parts of Section 377 (Indian Penal Code 1860) that criminalized consensual sex between adults in 2018 (Rajagopal 2018). The 2013 judgment prompted protests across the nation. Student and left allies in Kolkata, including participants from Ardhek Akash, helped organize a "grand rally" against the judgment on December 19, 2013. One of the organizers, Chhandak Chatterjee, explicitly critiqued previous left dismissals of sexuality relative to more "basic" class issues: "I've heard many left groups decry, "no thought for foodclothes-shelter, but excessive attention to sexuality!" But think once, brother, what if you were told you cannot kiss your wife? If you kiss her the cops will haul you off to jail? Brother, the BJP is coming to power ... it is this BJP that, along with some Hindu 
and Muslim fundamentalist groups, had opposed the Delhi High Court judgment" (Chatterjee 2013). ${ }^{10}$ Addressing an imagined figure, the typical "Bhadralok" leftist male ("brother"), the statement counters leftist suspicion of the liberal sexuality rights framework. It positions sexuality rights within a larger discourse of protest against state and police oppression, commonly espoused by the "independent" left since the Singur-Nandigram movements, as well as against right-wing fundamentalism. Such coalitional politics thus facilitates convergences between political frameworks that had remained hitherto distinct in West Bengal, while rupturing former continuities between the "left" and "right" on LGBT issues.

\section{Gendered hierarchies and limitations of trans acceptance}

However, the coalitions did not always function smoothly, and fault lines began to emerge at the outset. Despite the break from the conventional left, "independent" leftist student fronts show persistent patterns of male dominance and class/caste hierarchies, which have constrained trans participation within such spaces. This critique, gleaned from personal narratives of trans/kothi activists like Raina and Sumi, is not directed at any specific student collective. "Independent" student spaces are fluid and activists flow between different fronts and collectives. Relations between different student groups have tended to be dynamic and evolutive, sometimes evidencing intense disagreement. Thus, hierarchical tendencies are neither homogenous nor attributable to particular fixed groups, but may surface-and also be resisted or ruptured-across various collectives or spaces.

21 Early on in their collaborations with student groups, Raina and Sumi received a mixed reception from the broad spectrum of students who attended these events. While groups like Ardhek Akash are strongly committed to including trans people in activist spaces, the larger masses of students within which such collectives are embedded manifested varied reactions to the presence of trans people, including persistent curiosity about, and an objectification of, trans bodies. After a gathering at Jadavpur University in June 2013, Raina noted, "I spoke at a street corner on the Jadavpur campus ... a crowd gathered seeing a kothi like me speaking in a place like Jadavpur!" Sumi also noticed how her very presence in leftist student spaces sometimes provoked surprise and unease. In the summer of 2015, while on her way to a panel discussion on intersectionality in Kolkata, she met some cisgender female students who were also on their way to the discussion. Sumi narrates that, "two of the women made a strange face after hearing that I was one of the speakers ... like turning up their noses (nak-shitkano) ... they didn't say anything explicitly, but one can still understand things left unsaid!" She also noticed adverse reactions during the panel discussion itself: "I saw that some well-known student leaders were laughing during my statement, not giving it that much importance." While incidents like this may be glossed over as microaggressions (Wing Sue 2010)-difficult to verify or call out-precisely for this reason, they contribute to creating a transphobic and unwelcoming atmosphere.

Sumi also noted the ways in which gendered subordination and class/caste hierarchies may contextually reinforce or undercut each other, resulting in trans people from differing class/caste backgrounds being treated differently in "progressive" spaces: "In 2016, I went to the little magazine fair at Kolkata, where I happened to meet Manobi 
Bandyopadhyay (a well-known trans activist). Some students from Presidency University were also there ... whom I'd met at various activist programs ... but I noticed that they avoided me and talked to Manobi, though I was standing right beside her!" For Sumi, this incident underscored the relatively high status of upper caste urban LGBT activists like Manobi and the redoubled marginality of Dalit and rural trans people like herself. Sumi also noted that students treated her with more respect when she was with me, an Anglophone academic from a privileged class/caste background. Her critique suggests that the social convergence of elites across LGBT and student spaces limits the class-disrupting potentials of left-trans-queer alliances.

Equal participation of trans people is also undercut by the way in which revolutionary leadership is often gendered male in leftist spaces, subordinating both cisgender women and trans people. Raina observed, "I started noticing patriarchal tendencies across both leftist parties and the non-party left, though there is much to learn from them as well ... most of the time, men would lead the slogans ... male seniors carried a certain special power. Competition about who would be on the front lines was prominent even among these groups!" At an event in June 2013, she spoke out against a persistently masculinist rhetoric of revolution in which biplobis or revolutionaries were often gendered male: "There was this intolerable man ... who was lecturing ... that boys should become revolutionaries ... I objected, saying do revolutionaries have a gender?" In this scenario, women were potential allies: "when I first spoke at street-corner protests among independent left groups, it was the women who would come up and speak to me."

24 Yet both Raina and Sumi felt that women were not always able to access higher levels of leadership. Sumi said:

While participating in a panel discussion in 2015, I felt many times that the women who were present were not really in charge of managing the event, the speakers or audience ... some of the male leaders were in charge of such things ... one woman did read a statement on intersectionality at the beginning, but I heard an audience member joke to her boyfriend, "you do not like it when she mouths such feminist statements, do you?" ... many male activists from Kolkata universities write feminist statements, I doubt how much of that they really believe and practice!

While women did play leading roles in other events, Raina felt that they were relegated to certain kinds of activism (especially around gender), and men tended to retain leadership in more "general" spaces. Raina also noted the relative absence of explicitly Dalit-identified feminists within the "independent" left, though some female activists were from oppressed caste backgrounds. ${ }^{11}$ However, some student groups did attempt to address latent hierarchies around gender and caste. For instance, in 2016, activists associated with Ardhek Akash and related overlapping collectives organized internal discussions on gender, sexuality and intersectionality, where participants critically examined their privileges and disprivileges, and men endeavored to be self-reflexive about their gendered and class-caste positions.

Nonetheless, sometimes even seasoned activists have lapsed into forms of gendered condescension toward working class/Dalit trans people, positioning them more as pathetic victims than as agents or equal participants in activism. In October 2015, Chhandak Chatterjee-the activist who had critiqued the leftist dismissal of sexualitypublished a public post on Facebook against a case of transphobic violence. Chatterjee sought sympathy for the survivors in a melodramatic narrative about trans women who desperately try to pass as women and cry when looking at their genitalia-tropes 
highly reminiscent of the "pathetic trans" archetype critiqued by Julia Serano (2007:35). Ventriloquizing trans voices, Chatterjee wrote: "if people laugh at me, I fear ... does that mean that my waxed hands still show hair? ... one cries again after reaching home, for that day I could not become a woman ... one hates one's genitals... God, I'd just wanted to become a woman!"12

In a panel discussion in January 2016, Sumi vehemently objected to this narrative: "this ends up depicting kothis as if they are always helpless ... but not everyone is... and do we not have any other aim in life other than becoming women? For many, obtaining food is a bigger problem ... and not all trans people are pained or ashamed of their genitalia!" Chatterjee was not present; when I brought up the issue in a comment under his post, he replied that he had meant the post only as "one version" among many potential transgender narratives.

Such "pathetic trans" portrayals also occasionally emerged at protest meetings comprising students from Ardhek Akash and related collectives. For example, at a protest in Kolkata in 2015, a speaker described hijra professions, such as blessing people for money, as not just a limited employment choice given the lack of mainstream options, but also as a particularly pitiable one: "just think ... what if you had to put on garish make-up and wear sarees to go beg for money?" In response, I pointed out that hijras may be proud of their professions. The speaker, a young woman who is otherwise a passionate advocate of trans rights, was very receptive to the dialogue. Thus, depending on the context, hierarchizing tendencies may be more or less easy to counteract, given the diversely gendered constituency and uneven concentration of power among student activists.

\section{Regulating dissent}

Ideological schisms around particular issues posed another tactical problem for trans activists collaborating with student collectives. Such divergences may take the shape of clashes between distinct groups, or internal differences within student collectives that leaders may attempt to suppress. In both cases, trans activists experience pressure to delimit their political allegiances in order to maintain alliances.

These tendencies came to the fore during protests against right-wing nationalism in February 2016. On February 9, 2016, student activists at Jawaharlal Nehru University (JNU) in Delhi held a protest meeting supporting self-determination in Kashmir and questioning the hanging of Afzal Guru, a Kashmiri man who was executed, despite insufficient evidence, for his alleged links to a 2001 "terrorist" attack on the Indian parliament (Chatterjee 2016). The activists were attacked by the right-wing student group, ABVP, and dubbed "anti-national" in the media; some were subsequently arrested. Students at Jadavpur University organized a rally protesting the arrests and the suppression of campus democracy. The organizers followed the lead of Hok Kolorob in not associating with any political party. While they condemned right-wing "fascism" and "terror," they also sought to overturn the "anti-national" allegation by positioning themselves as true patriots, who loved the land and people of India, in contrast to the fascist state that was actually betraying the country by suppressing democracy: "let our revolutionary pledge burn down the unjust Indian state; let the light of our torches sanctify our motherland India" (Sit, Dasgupta and Mukhopadhyay 2016a). ${ }^{13}$ One participant published a post stating that the right-wing fascists were the true "anti- 
nationals" (deshdrohi) who would be destroyed through revolutionary patriotism (deshprem). ${ }^{14}$

However, this attempt to reclaim patriotism against statist deployments of nationalism proved to be an unstable move that collapsed under pressure into liberal nationalism. During the rally, some people, associated with a far left group called Radical, shouted slogans supporting Kashmiri freedom (azaadi) from India and condemning Afzal Guru's execution. As in Delhi, the media labeled them "anti-national" and the police cracked down on the protestors (Banerjie 2016). The organizers responded by quickly distancing themselves from any "anti-national" viewpoint:

We organized today's rally to condemn the state atrocity against the students invoking nationalism... However, a section of the media is trying to portray today's rally as a "pro-Afzal" one. This press statement univocally condemns this mal-effort (sic) ... There may be the possibility of "anti-India" sloganeering by some fringe elements in the gathering. But ... these slogans don't depict the spirit of the rally at all. If any such incident happened in the gathering, violating the common minimum program of the rally, we strongly condemn that. (Sit, Dasgupta and Mukhopadhyay 2016b) $)^{15}$

Another participant in the rally condemned "fractions ... with their own vested interest" for risking the "unity of the general mass" with their "extremist views." 16

Here, the old left bogey of threats to mass unity-which, as Omvedt (1994:37) notes, was used to condemn social movements around gender or caste-is evoked to label and silence dissenting voices as "extremists" and "fringe elements." The condemnation of dissenters as pursuing vested interests evokes the declaration of independence from "governmental, power-centric political organizations of different colours but of similar vested interests" by Hok Kolorob activists (Times News Network 2014). Ironically, the political goal of independence from "governmental" political organizations is refashioned here into a disciplinary technique (Foucault 1990:140; Joseph 2012:35)—one that seeks to regulate dissent and discipline activists into proper revolutionary conduct by condemning outliers as politically extremist factions that threaten the wider interests of the independent student mass, thus implicitly consigning them to punitive police action.

These attempted strategies of governance demonstrate how the patriotic critique of the "unjust Indian state" buckled under pressure, and sought to discipline the students into a unified body, replicating the nationalist suppression of "anti-India" stances to produce a unified nation-ironic for a rally that had been organized precisely to protest the stifling of "anti-national" dissent. This irony was not lost on other activists. One activist, Agniswar, wrote: "No such slogan was raised at the rally that would need to be disavowed... I personally think that the highest court committed an extreme injustice in hanging Afzal Guru... And are the hopes of Kashmiri people for self-determination unjustified? ... (It is) political poverty ... to not take a stand against the relentless campaign to taint the right to self-determination of a people as 'separatist."'17

Within this fractured political terrain, alliances became a fraught question for trans activists. Like Agniswar, Raina questioned the dissociation from "extremist" viewpoints. At an event at Jadavpur, she said, "if we don't stand by the accused when an arrest warrant is issued based on the Kashmir issue, then people in the opposition are acting like the state themselves!"

In response to her critique of the statist imbrications of independent student politics, some student activists accused Raina of siding with Naxalite (Maoist) political groups, 
as opposed to "bannerless" collectives: "Some of them said that I was propagating a Naxalite ideology ... which would result in fragmentation of the country... sometimes I heard I was an anti-nationalist ... but we were ourselves often branded Naxalites when we spoke at street-corner protests ... should we not stand with people labeled Naxalite? ... at one point, one of the senior male leaders became angry and screamed at me!" She remarked, "they call themselves the non-party left ... but some of them belong to a stereotypical authoritarian leftist structure only!"

However, other student activists were more open to dialogue on the issue. In July 2016, Ardhek Akash organized an event supporting Kashmiri self-determination titled "Ravaged Kashmir: Aspiring for One Sky," where trans activists were invited to speak alongside speakers from Kashmir. Significantly, Ardhek Akash members utilized repertoires of protest drawn from the Hok Kolorob movement that had also been evoked in the February rally, including similar slogans. For instance, one poster made for the event, bearing the message "andoloner bohu shoor/ Kashmir theke Manipur" (the movement has many tunes/ from Kashmir to Manipur), referenced the Hok Kolorob slogan "lathir mukhe gaaner shoor/dekhiye dilo Jadavpur" (Singing in the face of batons/ is the way shown by Jadavpur). Such crossovers demonstrated how authoritarian tendencies could not contain conversations and flows of ideas across ideological divides, pointing the way to a more fluidly structured left in which trans activists continued to participate.

\section{Commoditization and sex work}

Another significant ideological fault line concerned the critique of the commoditization of feminized bodies in professions like sex work and the entertainment industry. This raises a question central to the conjuncture of leftist, feminist and trans activism, regarding how an intersectional critique of patriarchy and capitalism should be articulated. Feminists in India, like their counterparts transnationally, hold a variety of positions on sex work. They include abolitionists who see the sexual marketplace as inevitably objectifying and enslaving women who must be "rescued" or "rehabilitated," feminists who advocate for sex workers rights considering them the same as those of other laborers, and "middle ground" feminists who support sex workers' rights, but seek to ultimately dismantle the sexual marketplace (Kotiswaran 2011:31-35). Kolkata is a rich site for such debates-it has a globally known sex workers' collective (Durbar Mahila Samanwaya Committee), as well as various anti-trafficking groups that express a range of positions on sex work, from the "middle ground" to abolitionism.

Within this contested terrain, Ardhek Akash and related leftist-feminist student collectives have avoided taking a strong public stance on sex work per se. However, they have organized several protests targeting the commoditization of women's bodies in the capitalist marketplace in more general terms, drawing from both Marxist critiques of commodity fetishism and the radical feminist critique of female objectification. For instance, a street event organized by Ardhek Akash in May 2013, titled "Nari Ponyayon-Dhorshon" ("Women's Commoditization and Rape"), sought to draw connections between rape culture and the commoditization of women's bodies in films, advertisements and pornography (Indialatest 2013). The event evidenced varying political approaches, manifested in a rich plethora of (largely Bengali) posters displayed on the pavement or carried by speakers. Some posters critiqued the 
sociocultural reception of female bodies and distinguished agential self-expression from objectification: for example, "if you see a woman's cleavage or curves, do not think of her as an object for consumption!" Another English-language poster cited Marilyn Monroe: “I don't look at myself as a commodity, but I'm sure a lot of people have." But other posters critiqued any sexualized display of women's bodies as wholly symptomatic of market-driven commoditization, ignoring the intentions or agency of women who perform such display labor: "stop the vulgar commoditization (asleel ponyayon) of women's bodies in films and advertisements!"; "to sell leather goods one need not sell women as flesh!"; "women are not objects for your sexual pleasure, discard the culture of sexualization!" At a subsequent protest in June 2013, organized by a broad coalition of activists, some participants wanted to burn newspapers carrying advertisements displaying women's bodies.

While not addressing sex work directly, these positions parallel radical feminist critiques of sex work and may similarly lapse into a unidimensional understanding of power. The entry of women into sexual marketplaces can only be perceived as the "reduction of women's bodies to a singular, objectified image and function" and sexual labor is conflated with "the summary objectification of women" (Shah 2012:28). Such stances also echo conservative moralism; a censorious critique of the "vulgar" (asleel) sale of feminized bodies in capitalist marketplaces tends to erase the complex interplay between objectification and agency, thus erasing the labor-based struggles waged by sex workers and entertainment workers (Kotiswaran 2011:31).

At the aforementioned event of May 2013, the potential lapse into moralism was reflected in posters that critiqued female entertainers for fostering commoditization. Referencing a Bollywood song sung by the playback artist Shreya Ghoshal, and featuring actress Kareena Kapoor, one poster read: "when they sing 'I am a tandoori chicken,' don't Shreya or Kareena have any sense of self-respect?" The emphasis on a proper sense of "self-respect" (atmoshomman) based on bodily sovereignty, which precludes erotic pleasure in objectification, was further elaborated in a subsequent online discussion on Facebook among activists associated with Ardhek Akash. One activist opined: "if a woman sacrifices her own selfhood (satta) ... then the fault of those who use that is merely an excuse." Another activist argued that such an approach to the female body is the result of social conditioning, rather than the actions of actors or models per se: "I learn from my childhood, from the television, from magazines ... that if I cannot have a 'zero figure' then I'm bad ... through such education ... I am ... making myself into a commodity." 18

This conversation reflects more general attitudes to sexual labor that run through both party-affiliated and "independent" student groups. Sumi noted, "in Coochbehar, I heard student activists from the SFI (the student wing of the CPI(M)) say, why would anyone do sex work? There are so many professions, why choose to do that?" In Kolkata, Raina narrated a similar conversation with two independent leftist activists: "they saw sex workers only as victims ... they asked me, why don't they want to do any other work? ... what will happen to them in their old age, they'll have no recourse but to beg!"

41 Thus, any form of willing sexualized labor is rendered illegible. Women engaged in this type of labor are understood either as victims duped into sacrificing their selfhood, or as perverse agents who make unintelligible choices and lack "self-respect." Here, disciplinary and regulatory forms of power, as seen above in the attempt to censure 
"anti-India" slogans, give way to a governmental technology that works through the evocation of a sense of sovereignty and freedom proper to the self, seeking to produce free agents rather than docile bodies (Joseph 2012:35; Foucault 2007:353). Proper feminine conduct must be achieved by cultivating a proper sense of agency and selfregard resistant to social conditioning that transforms it into commoditized femininity. The consequent reduction of sex workers to either victims or perverse agents means that they cannot be fully envisaged as revolutionaries and equal participants in movements.

In this context, community members belonging to the trans collective Samabhabona, who performed sex work among other professions, felt uncomfortable with a blanket anti-commoditization rhetoric. Raina said, "when I saw posters against women's commoditization, many questions began to occur to me ... wasn't there commodification in other trades? ... when they would say anti-sex work stuff, I would feel afraid, because I have done sex work myself."

However, Raina's discomfort with critiques of commoditization did not crystallize into a binary opposition between governmental forms of leftist/feminist activism and trans sex workers. Stances against commoditization are complicated by internal ambiguities within leftist student discourses around questions of feminine self-expression. The freedom to dress and express oneself as one pleases exists in tension with the idea of loss of selfhood through commoditization. Slogans like "fix your mentality before you ask me to fix my clothes" had become popular during the anti-rape protests of 2012-13, in which Ardhek Akash members also participated. Samabhabona members took advantage of these ideological openings to advance a dialogue on sex work. In a meeting at Jadavpur in June 2013, Raina said, "we live within a capitalist society where all kinds of labor are commoditized ... not just women's bodies but even men's bodies are commoditized in ads ... a woman could button down her shirt just because she is feeling warm ... but even then, we tend to think her cleavage is being displayed."

Significantly, Raina's argument drew upon two discursive elements from leftistfeminist student activism-firstly, the general Marxist critique of commoditization as endemic to all forms of labor under capitalism, and secondly, the right to selfexpression in opposition to dehumanizing forms of objectification. Indeed, her statement closely echoed the Ardhek Akash poster, "if you see a woman's cleavage or curves, do not think of her as an object for consumption!" Combining these two elements, she questioned the exceptional status of sex work and positioned it as just another form of commoditized labor. She explained this exceptionalism by referencing how women are reduced to their embodiment in a way that men-even those who perform sexualized labor-are not. In subsequent conversations with Ardhek Akash members, Raina attempted to redefine sex work as a particular "kind of service" rather than a sacrifice of selfhood. She tried to relocate the problem in the objectifying way in which women's sexual labor was reduced to the loss of selfhood in its entirety, rather than perceived as a specific embodied service like other forms of commoditized labor.

Raina's critiques encountered a mixed reception: "the younger women listened empathetically ... during protests, they also mixed freely with kothi sex workers, and heard them talk and joke about their work." However, some of the senior male activists had more fixed ideological stances: for instance, the idea that sex work only existed under capitalism and would disappear under socialism. Raina countered that even under socialism, sex could be provided by professionals as a non-transactional service. 
In response, "they provided more theories," and no consensus was reached. Thus, there was again a tension between recalcitrant leftist ideological positions and an internal discursive flexibility that allowed Raina to redeploy student activist rhetoric to create a more complex negotiation with sex work.

\section{In conclusion: scale versus sustainability}

Given these uneven interactions with the "independent" left, replete with both tensions and solidarities, trans collectives have strategically streamlined collaborations with non-LGBT leftist student groups, often preferring to work with younger women activists from collectives like Ardhek Akash, especially those from working class or Dalit backgrounds..$^{19}$ In such cases, achieving perfect ideological alignment may be less important than building upon broader forms of affective and tactical solidarity. For example, though student activists may not explicitly support trans sex workers' rights, Raina noted that they were often the first to mobilize against cases of violence against poor or Dalit trans persons, including sex workers: "they mobilize much more quickly than LGBT organizations in some cases!" Indeed, non-funded trans-kothi-hijra community organizations outside Kolkata, like Nadia Ranaghat Sampriti Society, have relied on Ardhek Akash members to respond rapidly to instances of violence in the absence of funded infrastructure or resources.

While such refigured alliances show how collaborations with student activist spaces have sustained themselves despite hurdles, the very need to strategize alliances also means that the liberatory promise of mass movement building, which seemed apparent in the heady initial days of collaboration, becomes qualified and limited. As alliances deepen, fragmentations and hierarchies become more apparent; these may be overcome at smaller scales, but not to the extent of a wholesale structural transformation of leftist spaces that would be necessary to reinvigorate their revolutionary promise. Transformative alliances among non-LGBT leftists and transkothi-hijra activists become more localized, based on individual friendships and solidarities. Such alliances may "scale up" to reach a critical mass around specific issues such as IPC 377 (Indian Penal Code 1860) or specific cases of sexual assault, but mass solidarity remains issue-based rather than a long-term process. LGBT issues drift in and out of the left focus in a shifting terrain of political expediency. Thus, there seems to be a tension between the scale and sustainability of collaborations-we see either sustained micro-level alliances or scaled-up coalitions in the short term, but we do not find a long-term macro-level solidarity between student and trans/queer groups, and this limits the transformative potential of these solidarities.

To conclude, the conjunctures between trans-kothi-hijra and student collectives raise uncertain and unexpected political possibilities. By creating a bridge between students from varied socioeconomic backgrounds and working class and Dalit trans, kothi and hijra communities, these collaborations disrupt the leadership of metropolitan elites within both LGBT and left movements. These alliances evidence a non-linear trajectory of political tendencies that challenges a teleological idea of progress. Student collectives like Ardhek Akash veer between quasi-moralistic critiques of sex work and the defense of gender and sexual self-determination. Independent left spaces nurture Dalit women working intersectionally on trans issues, and yet retain male leaders with some degree of hegemonic control. The discursive terrain divagates towards radical 
feminism, Marxism, patriotism, liberal rights-based frameworks and intersectional critique-and all of these tendencies co-exist and feed off each other. This is an assemblage that illustrates the impossibility of adopting a purist stance on political praxis, and the irreducibility of transformative politics to any form of single-axis identitarian mobilization, while reiterating the significance of the social location of the participants in processes of political organizing.

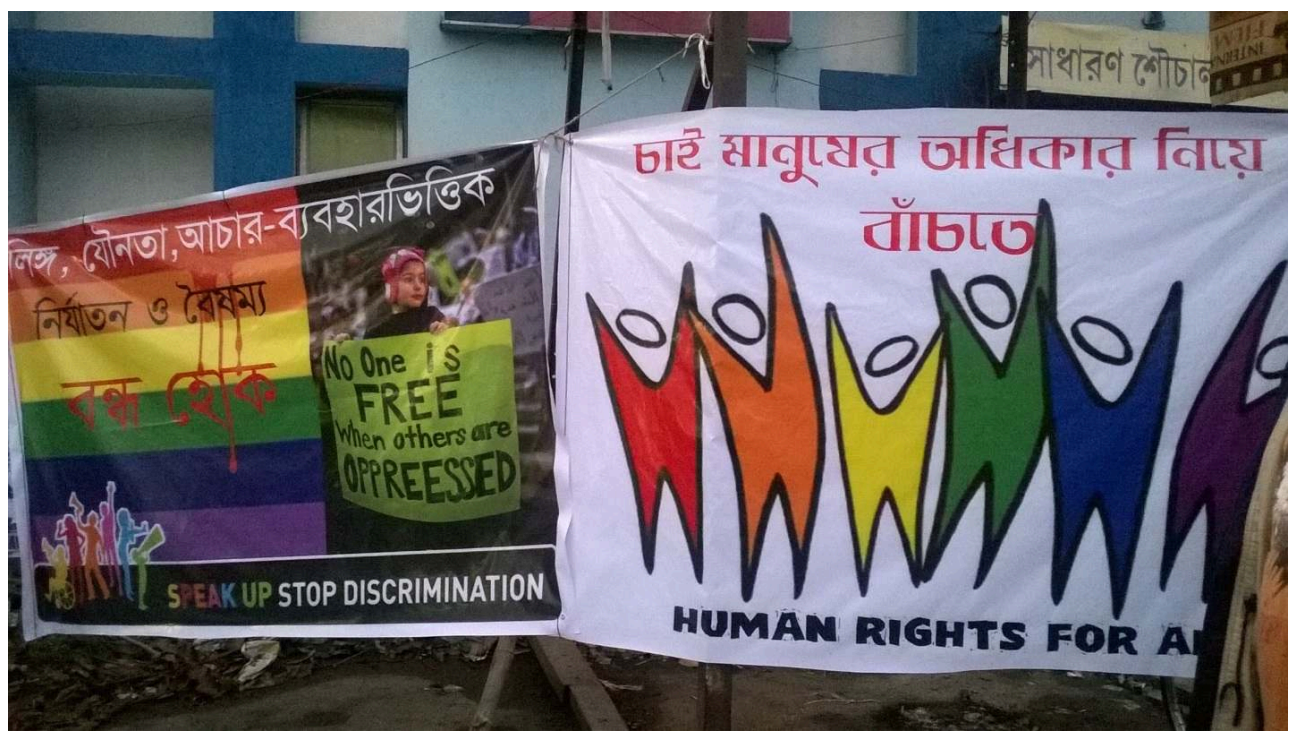

"End persecution and discrimination based on gender, sexuality, behavior and expression" and "We want to live with human rights": Multilingual banners at a street protest against violence against trans persons, organized by Ardhek Akash and Samabhabona, Kolkata, January 2015.

All pictures were taken by Aniruddha Dutta in West Bengal, India, between 2015 and 2016.

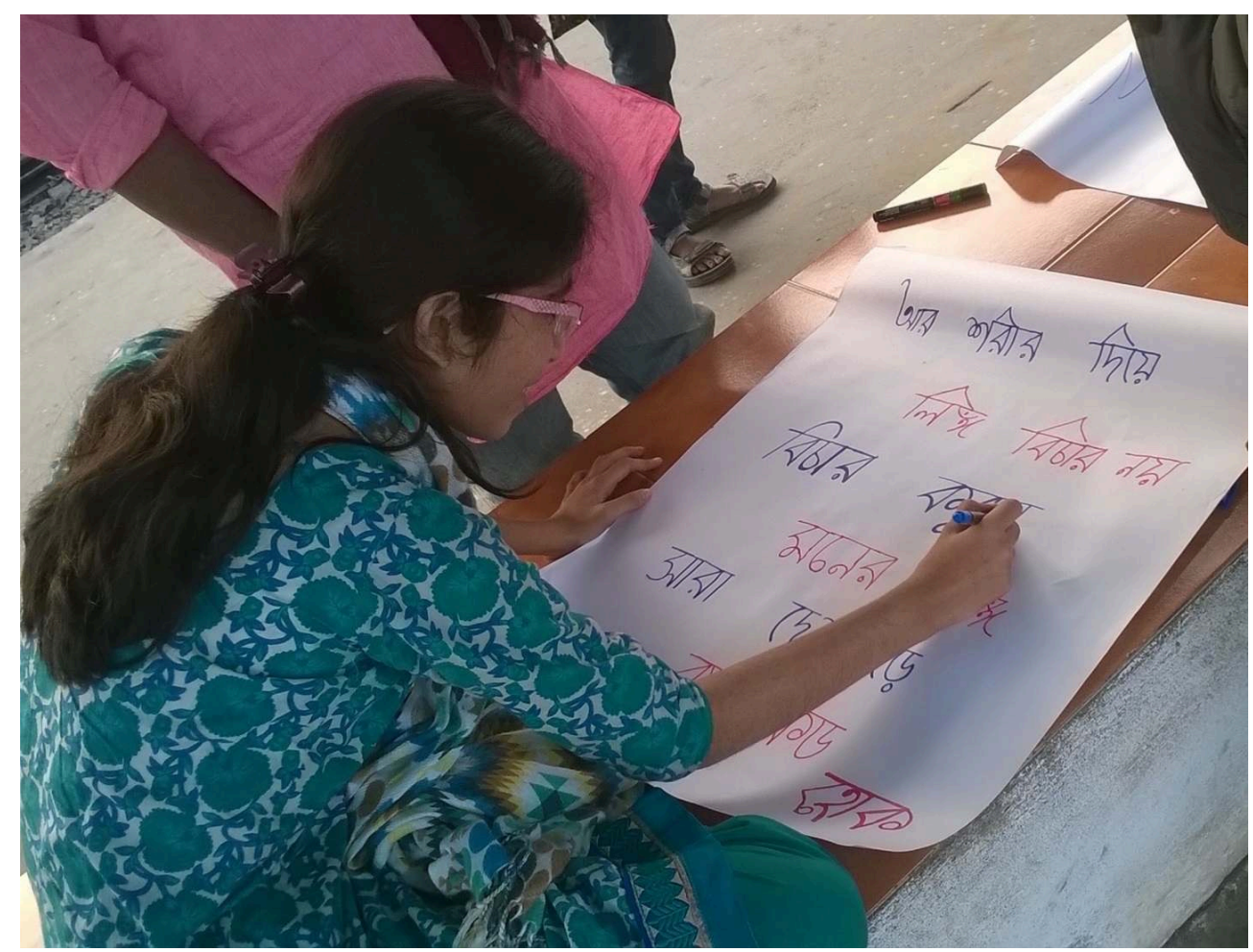

"No more judging gender by the body, consider the gender of the mind": An activist associated with Ardhek Akash makes a poster at Shantipur, West Bengal, January 2016.

All pictures were taken by Aniruddha Dutta in West Bengal, India, between 2015 and 2016. 


\section{BIBLIOGRAPHY}

Babui, Basahin. 2015. "Nirjatito rupantorkamider pokkho theke khola chithi." Facebook (Public Post), January 1. Retrieved November 12, 2017 (https://www.facebook.com/photo.php? fbid=1515868312035583\&set=a.1377955492493533.1073741828.100008372854511\&type=1).

Banerjie, Monideepa. 2016. "Now, Kolkata Students Use Pro-Afzal Guru Slogans at Rally." NDTV, February 17. Retrieved November 12, 2017 (https://www.ndtv.com/india-news/now-kolkatastudents-use-pro-afzal-guru-slogans-at-rally-1278166?site=full).

Bargi, Drishadwati. 2014. "Beef, Babasaheb and Bhadralok." Kindle magazine, May 2. Retrieved February 25, 2018 (http://kindlemag.in/beef-babasaheb-bhadrolok/).

Bose, Sumantra. 2011. "The End of an Era in West Bengal and India." Al Jazeera, May 18. Retrieved November 12, 2017 (http://www.aljazeera.com/indepth/opinion/ 2011/05/201151714194716872.html).

Chatterjee, Chhandak. 2013. "Gathering and Grand Rally against Supreme Court Verdict on 377." Facebook (Public Event), December 12. Retrieved November 12, 2017 (https://www.facebook.com/ events/371169239686676/permalink/371187586351508/).

Chatterjee, Rituparna. 2016. "Student Describes What Actually Happened at the Jawaharlal Nehru University on Feb 9.” HuffPost India, February 14. Retrieved November 12, 2017 (http:// www.huffingtonpost.in/2016/02/15/jnu-arrest_n_9233910.html).

Desai, Manisha. 2016. Subaltern Movements in India: Gendered Geographies of Struggle against Neoliberal Development. London and New York: Routledge.

Dutta, Aniruddha. 2012. "Indian Sexual Minority Communities Devastated by Funding Cuts." World Policy Blog, July 23. Retrieved November 12, 2017 (http://www.worldpolicy.org/blog/ 2012/07/23/indian-sexual-minority-communities-devastated-funding-cuts).

Dutta, Aniruddha and Raina Roy. 2014. "Decolonizing Transgender in India: Some Reflections." TSQ: Transgender Studies Quarterly 1(3):320-37.

Rajagopal, Krishnadas. 2018. "Section 377 Will Not Apply to Consensual Same-sex Acts, Says Supreme Court.” The Hindu, September 6. Retrieved September 6, 2018 (https:// www.thehindu.com/news/national/verdict-on-section-377-and-gay-rights-live-updates/ article24878751.ece).

Foucault, Michel. 1990. The History of Sexuality, Volume I: An Introduction. New York: Vintage Books.

Foucault, Michel. 2007. Security, Territory, Population: Lectures at the College de France. Basingstoke: Palgrave Macmillan.

Ghoshal, Devjyot. 2014. "A Brief History of \#HokKolorob, the Hashtag That Shook Kolkata." Quartz, October 9. Retrieved November 12, 2017 (https://qz.com/269774/hokkolorob-thehashtag-thats-defining-an-indian-student-protest-against-violence/).

Indialatest. 2013. "Public Program on Sexuality, Patriarchy, Commodification in Kolkata." The Unindian Times, May 31.

Indian Penal Code. 1860. Section 377 in the Indian Penal Code, "Unnatural Offences." Retrieved April 16, 2019 (https://indiankanoon.org/doc/1836974/). 
Joseph, Jonathan. 2012. The Social in the Global: Social Theory, Governmentality and Global Politics. Cambridge: Cambridge University Press.

Karim, Lamia. 2011. Microfinance and Its Discontents: Women in Debt in Bangladesh. Minneapolis: University of Minnesota Press.

Kotiswaran, Prabha. 2011. Dangerous Sex, Invisible Labor: Sex Work and the Law in India. Princeton: Princeton University Press.

Kranz, Susanne. 2015. Between Rhetoric and Activism: Marxism and Feminism in the Indian Women's Movement. Zurich: LIT Verlag.

Mandhana, Niharika. and Anjani Trivedi. 2012. "Indians Outraged over Rape on Moving Bus in New Delhi.” The New York Times, December 18. Retrieved November 12, 2017 (https:// india.blogs.nytimes.com/2012/12/18/outrage-in-delhi-after-latest-gang-rape-case/).

Muktangan. 2009. "Samakamita aparadh noy, Dilli high court-er jugantokari ray." Retrieved November 12, 2017 (http://nirmanblog.com/admin/4728).

Omvedt, Gail. 1994. "Peasant, Dalits and Women: Democracy and India's New Social Movements." Journal of Contemporary Asia 24(1):35-48.

Ray, Raka. 1999. Fields of Protest: Women's Movements in India. Minneapolis: University of Minnesota Press.

Roy, Srila, ed. 2012. New South Asian Feminisms: Paradoxes and Possibilities. London: Zed Books.

Roy, Srila. 2017. "Enacting/Disrupting the Will to Empower: Feminist Governance of 'Child Marriage' in Eastern India." Signs: Journal of Women in Culture and Society 42(4):1-25.

Serano, Julia. 2007. Whipping Girl: A Transsexual Woman on Sexism and the Scapegoating of Femininity. Berkeley: Seal Press.

Sit, Saikat, Priyasmita Dasgupta, and Shounak Mukhopadhyay. 2016a. "JNU-te Rashtriyo ebong Geruwa Shontrasher Protibade Moshal Michhil." Facebook (Public Event), February 16. Retrieved November 12, 2017 (https://www.facebook.com/events/540295979477486/).

Sit, Saikat, Priyasmita Dasgupta, and Shounak Mukhopadhyay. 2016b. "Official Press Release from the Organisers of the Protest Rally at JU." Students against Campus Violence (Public Facebook Page), February 16. Retrieved November 12, 2017 (https://www.facebook.com/ studentsagainstcampusviolence/posts/572758959566366).

Soderlund, Gretchen. 2005. "Running from the Rescuers: New U.S. Crusades against Sex Trafficking and the Rhetoric of Abolition." Feminist Formations 17(3):64-87.

Shah, Svati. 2012. “Sex Workers' Rights and Women's Movements in India: A Very Brief Genealogy." Pp. 27-43 in New South Asian Feminisms: Paradoxes and Possibilities, edited by S. Roy. London: Zed Books.

The Telegraph. 2015. "SFI Loses Student Union.” The Telegraph, January 30, p. 1.

Times News Network. 2014. “Campus Violence: Jadavpur University Promises to Keep 'Kolorob' Decibel High.” The Times of India, September 25. Retrieved November 12, 2017 (https:// timesofindia.indiatimes.com/city/kolkata/Campus-violence-Jadavpur-University-promises-tokeep-kolorob-decibel-high/articleshow/43358148.cms).

Wing Sue, Derald. 2010. "Racial Microaggressions in Everyday Life: Is Subtle Bias Harmless?" Psychology Today, October 5. Retrieved November 12, 2017 (https://www.psychologytoday.com/ blog/microaggressions-in-everyday-life/201010/racial-microaggressions-in-everyday-life). 


\section{NOTES}

1. My translation from the original Bengali. As this article cites both Bengali and English textual material, I use endnotes to specify which textual excerpts are translated. All translations are from Bengali.

2. Given the complex spectrum of subject positions encompassed by these communities, I treat kothi, hijra, transgender and queer as broadly overlapping categories for the purposes of this article; in practice, these terms may be more distinct or continuous depending on context.

3. For example, the JU Queer Collective of Jadavpur University, Kolkata, was established in 2018.

4. I have used their real names with permission, given that they are public activist figures.

5. All direct quotes are taken from field notes and translated from the original Bengali.

6. These posters are collated from several separate events to offer an overall sense of their political repertoire; all translations mine.

7. My translation.

8. Cited from Ardhek Akash's Facebook group. Retrieved November 12, 2017 (https:// www.facebook.com/groups/116881118346714/).

9. Cited from Ardhek Akash's Facebook group. Retrieved November 12, 2017 (https:// www.facebook.com/groups/116881118346714/).

10. My translation.

11. On the contentious relation between leftist and Dalit politics in West Bengal, see Bargi (2014).

12. Translated from an untitled public post on Facebook. Retrieved November 12, 2017 (https:// www.facebook.com/photo.php?fbid=1056460214378046\&set=a.

163297573694319.37186.100000422336698\&type=3\&permPage $=1$ ).

13. My translation.

14. Translated from an untitled public post on Facebook. Retrieved on November 12, 2017 (https://www.facebook.com/aritra.majumder.96/posts/741336752669061?pnref=story).

15. My translation.

16. Cited from an untitled private post on Facebook; name and hyperlink withheld to protect confidentiality.

17. Translated from an untitled public post on Facebook. Retrieved November 12, 2017 (https:// www.facebook.com/agnichakra/posts/547697435392441?pnref=story).

18. Translated from an untitled private post on Facebook; names and hyperlink withheld to protect confidentiality.

19. Although this issue lies beyond the purview of this article, the emergence of LGBT student groups in West Bengal, like the JU Queer Collective (established in 2018), might forge new coalitions between student and non-student activists but also potentially make them more narrowly LGBT-specific.

\section{ABSTRACTS}

This article charts emergent solidarities and tensions between transgender activism and leftist and feminist students' collectives in and around the city of Kolkata in West Bengal, India. The article examines how these alliances disrupt hegemonic forms of leftist and LGBT activism, challenging both the primacy of class in leftist political organizing and single-axis identity politics based solely on gender or sexuality. The article further argues that these coalitional 
formations manifest a tension between the subversion of established political structures and the persistent reinscription of gender/class/caste hierarchies within activist spaces, corresponding to governmental forms of activism that seek to delimit proper conduct for participants. However, these tendencies cannot prevent unpredictable deployments of political discourses and strategies that disrupt hierarchies and enable convergences or collaborations across ideological or organizational divides. Thus, these unstable coalitions raise uncertain and unexpected possibilities that disrupt linear or teleological trajectories of political mobilization.

\section{INDEX}

Keywords: student politics, leftist movements, India, transgender, kothi, LGBT

\section{AUTHOR}

\section{ANIRUDDHA DUTTA}

GWSS, University of Iowa 